\title{
Plejaadid kui taevaavad, Linnutee ja neiu Kuul: kultuuriseosed Põhja- Euraasias
}

\begin{abstract}
Teesid: Läänemeresoome ja balti (Läti ja Leedu) kosmonüümide vahel ei ole suurt erinevust, kuid balti ja slaavi kosmonüümide mustrid erinevad teineteisest. Balti alade idaosas kutsutakse Plejaade Taevasõelaks või Sõelatähtedeks, Linnuteed Rändlindude Teeks ja Kuul usutakse nägevat kaelakookudega neidu. Enamasti nimetatakse Kesk-, Lääne- ja Lõuna-Euroopas Plejaade Kanaks Tibudega, kusjuures Linnuteele ja Kuu tumedatele laikudele on pakutud muid, tihti erinevaid tõlgendusi. Ida-Balti mudel on sarnane Kesk-Volgamaa omaga, kus see on levinud permisoome ja türgi rahvaste seas ning võib olla rauaaegse (proto-)balti kultuuri pärand. Siiski võib kõnealuste kosmonüümide puhul leida paralleele peaaegu kogu Põhja-Euraasias ja paiguti Põhja-Ameerikas. Näiteks veekandja Kuul on kõige levinum ning tuntud ka Jaapanis ja Polüneesias. Euraasia puhul on märkimisväärne, et põhjapoolsetel samojeedidel puuduvad kõik kolm kujundit. Kontrollimist vajab hüpotees, et vähemalt mõned tõlgendused kerkisid algselt esile Ida-Aasia põhjaosas vanema kiviaja lõpul ja levisid sealt edasi läände ja mööda Baltimaid lõuna poole.
\end{abstract}

Märksõnad: Aasia ja Ameerika kosmonüümide seosed, Linnutee, Plejaadid, Põhja-Euroopa muinasaeg, rahvaastronoomia, tumedad laigud Kuul

Väljaspool troopilist vöödet paiknevate Euraasia rahvaste tähelepanu on köitnud seitse peamist nähtust öises tähistaevas: Kuu oma tumedate laikudega, Veenus, Linnutee, Suur Vanker, Plejaadid, Orioni Vöö ja Põhjanael. Mõned rahvad on märganud teisigi planeete, tähti ja tähtkujusid, mis on omakorda jäänud teiste tähelepanuta. Kuigi Euroopast on teada arvukalt kosmonüüme, kasutatakse suuremat osa neist harva ning paljud on üksikute enamlevinud tõlgenduste variandid. Kosmoloogilise sõnavara ja nende abil sõnastatud mütopoeetiliste ideede konservatiivsus moodustab aga suurepärase allikmaterjali mineviku rahvuslike ja kultuuriliste arengujoonte uurimiseks.

Euroopa kosmonüümiline kaart annab alust arvata, et tegu on üsna kauge minevikuga. Mitmete hiljuti üleskirjutatud või kirjalikes allikates säilinud kosmonüümide levikuala ei kattu keelkondlike piiridega. See paistab eriti silma 
balti ja läänemeresoome keelte puhul, mis kuuluvad erinevatesse keelkondadesse, kuid mille kosmonüümi-sõnavara on identne. Kõikjal Balti alade idaosas kutsutakse Linnuteed Rändlindude Teeks, Plejaade Taevasõelaks või Sõelatähtedeks ja Kuul usutakse nägevat kaelakookudega neidu. Läänemerest lõuna ja lääne pool (v.a neil Poola ja Valgevene aladel, kus balti keeled asendusid üsna hiljaaegu slaavi keeltega (Gładyszowa 1960; Niebrzegowska 1999: 149; Vaiškūnas 2004: 169-170)), puuduvad (küll üksikute eranditega) Ida-Balti aladele tüüpilised kosmonüümid. Näiteks tunnevad Linnuteed Lausitzi sorbid (Azimov \& Tolstoi 1995: 118). Plejaadide tõlgendamist sõelana on üles tähendatud ungarlastelt (Mándoki 1963: 519-520; Zsigmond 2003: 434) ja mõningatel juhtudel itaallastelt (Volpati 1933a: 206). Kuul nähtav neiu on iseloomulik motiiv Makedoonias ja Kirde-Bulgaarias, üksikjuhtudel ka Rumeenias (Marinov 2003: 28; Mladenova 2006: 137, 263-264, kaart 29; Tsenev 2004: 47).

Hoolimata nimetatud eranditest jookseb balti ja slaavi kosmonüümide vahel selge piir. Selle puudumine baltlaste ja läänemeresoomlaste vahel pole samuti kaheldav. Millised ajaloolised protsessid võisid kaasa aidata selle piiri moodustumisele?

\section{Plejaadid kui taevaaugud}

Alustagem Plejaadidest. Kui jätta kõrvale Plejaadide seostamine inimrühmaga (sellelaadseid, kuid väga erisuguseid kujutelmi on üles kirjutatud erinevais paigus), on Euroopas levinud kolm peamist nimevarianti (Joonis 1, 1 - Kana ja Tibud, 2 - Metspardi Pesa ja 3 - Sõel).

Kosmonüümid Kana ja Tibud, Pesakond, Tibud, Noorkana jt on iseloomulikud Lääne-, Lõuna- ja Kesk-Euroopas, Balkanimaades ja Lääne-Ukrainas (Andree 1878: 106; Boneva 1994: 12; Tšubinski 1872: 14; Jankovitš 1951: 141; Krappe 1938: 152; László 1975: 604; Matičetov 1974: 49; Mladenova 2006: 89-93; Niebrzegowska 1999: 145; Smith 1925: 124; Svjatski 1961: 120; Volpati 1932: 194-205; 1933a: 507). Samas piirkonnas ei leidu neid nimevariante vaid suuremal osal endise Jugoslaavia aladel ja Püreneede rahvastel (v.a baskidel). Väljaspool Euroopat on Kana Tibudega tuntud Lääne-Aafrikas ja Sudaanis (Hirschberg 1929: 326-327; Meek 1931: 200; Schwab 1947: 413; Spieth 1906: 557; Volpati 1933a: 507), samuti Kirde-Indias ja Kagu-Aasias (Andree 1878; Smith 1925: 114; Vathanaprida 1994: 39-41).

On võimalik, et sama kosmonüüm oli minevikus käibel ka Lähis-Idas ja Põhja-Aafrikas (Volpati 1933a: 195), kuigi praegu kasutatakse Plejaadide nimetusena vaid araabiakeelset nimekuju Suraia ('lühter'). Tuareegid kutsuvad Plejaade Tibudeks (Rodd 1926: 226). Et kosmonüümi ei leidu vanades allika- 


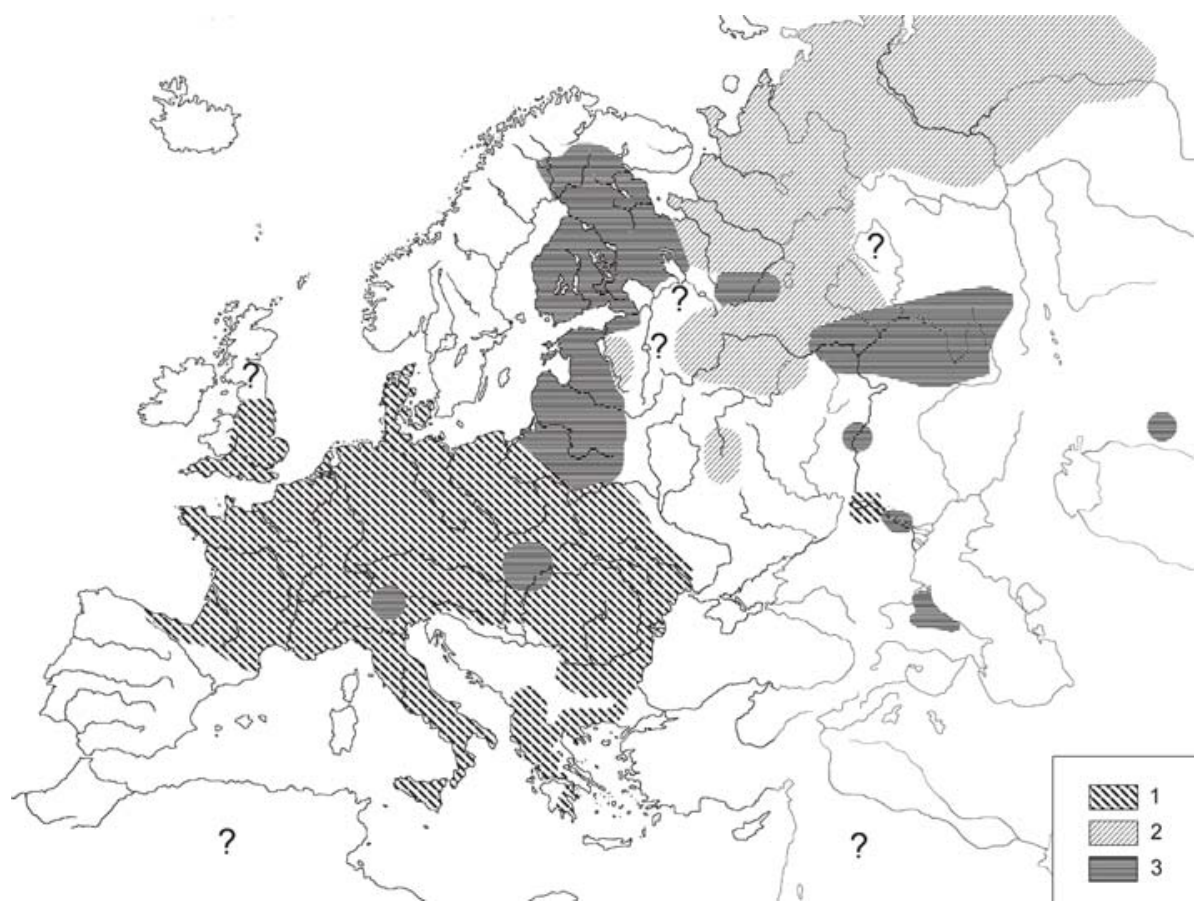

Joonis 1. Levinumad Plejaadide rahvapärased nimevariandid Euroopas: 1 - Kana ja Tibud, 2 - Mets)pardi Pesa või Pesakond, 3 - Sõel.

tes, mida vähemalt Itaalias on rohkesti säilinud (Volpati 1933a) ja kuna seda on seostatud vaid kodustatud kanaga, võib oletada kosmonüümi võrdlemisi hilist levimist Euroopasse.

Kosmonüüm, mis tähistab Metspardi Pesa (või Muna Mune) või Pardiperet, on tuntud neenetsite (Homitš 1974: 232), sürjakomide (Svjatski 1961: 120), udmurtide (Wichmann 1987: 214, 273) ja obiugrilaste seas (Munkácsi 1908: 255; 1996; Steinitz 1966-1993: 1412, 1636). Siberis ja Kirde-Euroopas on märgatav selle kosmonüümi kokkulangevus uurali keeltega, kuigi arvukate eranditega. Sölkupid nimetavad Plejaade Jäneseheiteks või Jänesepabulateks (Tutškova 2004: 212). Nimetuse tõlgendust enam ei teata, samuti pole sellel vasteid teistes kultuurides. Nganassaanidel tähistavad Plejaadid kütte, kes jahivad surnud inimeste ja põhjapõtrade hingi (Popov 1984: 48). Eenetsi nimel Kondiku (Dolgihh 1961: 24) puudub samojeedi etümoloogia või on see nimekuju üleskirjutamisel tugevasti moondunud (Sorokina 2008). Samas teavad türgi keelkonda kuuluvad hakassid Plejaade samuti Pardipesa või Pardiperena (Butanajev 1975: 238). Pardipesa kosmonüümi domineerimine Venemaa põhjaaladel (Potanin 1883: 730; Rut 1987: 15) on kahtlemata pärit eelslaavi substraadist. 
Venelaste liikumisel Uuralitest ida poole kandus Pardipesa nimetus Siberisse. Uno Harva viitab, et mõned uurijad on väitnud selle kujutelma olemasolu jakuutidel ja itelmeenidel (Lundmark 1982: 105; Mladenova 2006: 196), kuid need väited tuginevad ekslikule arusaamale. Nimelt pidas U. Harva (1933: 135) vene kosmonüümi Pardipesa ekslikult Plejaadide tõlkevasteks nendes keeltes. Maria Rut (1987: 47) on eenetsi allikatest kõneldes teinud arvatavasti sama vea.

Pardipesa kosmonüümi järjepidev ja selgelt eristuv esinemisala, mis jääb peamiselt Uurali keelte varasema levikuala sisse, kuid ületab nii samojeedide kui soomeugrilaste puhul keelepiire, lubab oletada, et see kosmonüüm on seotud mõne väljasurnud hõimuga. Isegi kui see rahvakild kõneles mõnda uurali keelkonda kuulunud keelt, pole neist jäänud otseseid keelejärglasi.

Nagu mainitud, on Plejaadide tõlgendamine Sõelana iseloomulik Ida-Balti aladele, kus seda on üles kirjutatud preislastelt, leedulastelt, lätlastelt, liivlastelt, eestlastelt, vadjalastelt ja soomlastelt (Allen 1899: 397; Andree 1878: 107; Ernits \& Ernits 2009; Kerbelyte 2001: 65; Kuperjanov 2003: 183-185; Mándoki 1963: 519; Nepokupnõi 2004; Vaiškūnas 1999: 167, 2004: 169). Vepslaste kohta puuduvad andmed, saamidel aga tähistavad Plejaadid neidusid (Tšarnolusski 1930: 48; Lundmark 1982: 105). Kesk-Volga piirkonnas on Plejaadide nimetamist Sõelaks talletatud tšuvaššidelt (Mándoki 1963: 520; Sirotkin \& Ivanov 1970: 128; Juhma 1980: 266; Zolotnitski 1874: 22), maridelt (Aktsorin 1991, nr 37: 83), tatarlastelt (Potanin 1883: 729; Vorobjov \& Hissamutdinov 1967: 316), baškiiridelt (Maksjutova 1973: 383) ja udmurtidelt, kuigi nähtavasti vaid lõunapoolsetelt hõimudelt (Nikonov 1973: 376; Wichmann 1987: 107). Volga aladel moodustavad ainsa erandi mordvalased, kes nimetavad Plejaade Mesipuuks (Svjatski 1961: 121). Sellist tõlgendust või sellele rohkem või vähem sarnaseid variante (Mesila, Herilasepesa) võib kohata venelaste, ukrainlaste, bulgaarlaste ja ungarlaste seas (Mladenova 2006: 115). Venelaste puhul on Sõela talletatud Plejaadide nimetusena Vologda oblastis ja Vene põlisalade piirist lääne poole siirdunud Vene emigrantide seas (Rut 1987: 15; Svjatski 1961: 121).

Lisaks Ida-Balti ja Kesk-Volga aladele on Sõel üsna levinud nimetus ka Dagestanis, kus seda on üles kirjutatud kumõkkidelt, lakidelt, avaaridelt, andidelt, dargidelt ja tavlidelt (Gamzatov \& Dalgat 1991: 304-305; Potanin 1883: 729-730). Grigori Potanin avastas, et Plejaade on nimetatud Sõelaks keskmise hordi kasahhide ja Astrahani tatarlaste seas (Potanin 1881: 126; 1919: 84). Arvatud pärsiakeelne vaste (Nepokupnõi 2004: 80) on väär, sest sõnad Parvin (Plejaadide vastena, tuletatud sõnast “esimene") ja Parvizan (Sõel) tulenevad erinevatest tüvedest (Steblin-Kamenski 2008). W. Bogoras ja W. Jochelson kirjutasid Aasia kirdeosa tšuktšidelt ja korjakkidelt üles kosmonüümid Ke'tmet 
ja Kä'tmäc (Bogoras 1939: 29; Jochelson 1908: 122) ja pakkusid selle tõlkevasteks Väike Sõel, kuigi vähemalt tšuktšid kujutasid Plejaade peamiselt naisterühmana (Bogoras 1939: 24). Ke'tmetile sarnane sõna tähistab tõepoolest sõela (mida kasutatakse lõhemarja pesemiseks), kuid mitte paleoasiaadi vaid jukagiiri keeles (Mudrak 2008).

Plejaade nähakse Sõelana peamiselt kahes suuremas ja kompaktsemas piirkonnas - Ida-Balti ja Kesk-Volga aladel. Ajalooliselt on neil ühist balti substraadi või mõjuga (Napolskihh 1997: 158-161) ning venekirve ja nöörkeraamika kultuuridega, mis olid levinud sinna juba varem (siinkohal jätan kõrvale küsimuse, kas nende arheoloogiliste kultuuride kandjate ja protobaltlaste vahel võib rääkida teatud järjekestvusest). Volga piirkonnas kandus see kosmonüüm hiljem soomeugrilastelt türgi rahvastele.

Napolskihhi arvamuse kohaselt võis Sõel jõuda Volga piirkonnast Dagestani ja Kasahstani keskmise hordi perioodil, kuigi nii hiline segunemine ei sobi kuigivõrd leedulaste ja lakide paralleeliga, mille kohaselt kasutas jumal Taevasõela vilja tuulamiseks (Halidova 1984: 160; Nepokupnõi 2004: 77). Paraku on see leedu müteem teada vaid kirjanduslikust allikast (Mitskevitš 1955, kd 8: 434) ja sellest ei piisa usutavate järelduste esitamiseks. Ungari allikates väljendatud seisukoht selle kohta jääb samuti ebaselgeks. Kuigi Plejaadide kohta kasutatav ungari sõna szita on slaavi päritolu laen (Mándoki 1963: 519520), nähakse seda tähtkuju tegelikult avaustena taevavõlvis (Zsigmond 2003: 434). Et selline kujutelm esineb Balkani rahvastest vaid ungarlastel, jääb küsitavaks, kas selline Plejaadide nimetus on laen Pannoonia slaavi hõimudelt. Ja kui ungarlased tõid selle endaga kaasa ida poolt, siis kust allikast see pärines? Lääne-Euroopas on kosmonüümi Sõel (crivello) kirjutatud üles vaid Põhja-Itaalia Alto Adige maakonnast (Volpati 1933a: 206; 1933b: 21). Tasub märkida, et crivello tähendab nii sõela kui ka tuulamiskühvlit.

Kokkuvõttes võib öelda, et Euroopas on Plejaadide Sõelaks nimetamise põhjused kõike muud kui ilmselged. Pole kindel, kas kõik versioonid pärinevad samast allikast. Ent kui vaadata taevakehade nimetusi terve Euraasia seisukohast, võib seda kosmonüümi tõlgendada ka üldisema ja laiemalt tuntud tähtede kui taevaaukude motiivi teatud variandina.

Selle kohta leidub paralleele Siberis, mida on rohkemgi, kui ülaltoodud Paleoaasia vasted. Plejaadide nimetuse etümoloogia türgi keeltes (ulker, yurker, yurkar jt) on kaheldav. Ühe hüpoteesi kohaselt on see seotud 'tuulutusava' või 'läbitorkamisega' (Nikonov 1980b: 296). Tuntud altai keelte uurija Anna Dõbo ei pea seda arvamust põhjendatuks (Dõbo 2008). Teisalt võiks seda kinnitada jakuudi rahvajutt, mille kangelane valmistas hundinahast labakud, et toppida kinni taevaaugud, kust puhus jäist tuult, ja mille kohaselt needsamad taeva- 
augud olid Plejaadid (Holmberg 1927: 418). Sahhalini ultšidel tähistasid Plejaadid mõnel puhul ka Seitset Avaust (Podmaskin 2006: 432), kuigi Alam-Amuuri piirkonnas oli tavapärasem nimetus Seitse Naist. Selle nimega pole seotud ühtki juttu, kuid sama sõna kasutatakse silmu lõpuseavade kohta (Pevnov 2008). Põhja-Euraasiast kaugemal leidub kujutelm Plejaadidest kui avaust ümbritsevatest tähtedest veel odžibve (ojibwa) rahva seas (Speck 1915: 48). Võttes arvesse asjaolu, et Aasia ja Põhja-Ameerika mütoloogiate vahele saab tõmmata teisigi paralleele (Berezkin 2006), ei saa välistada ajaloolist seost selle kujundi ja Siberis levinud arusaamade vahel.

Kuna peale Plejaadide on taevaaukudega seostatud ka muid tähti, teatakse seda motiivi Aafrikas, eriti Libeerias, Kongos, Somaalias ja Lõuna-Aafrikas (Kaptšits 1997: 15-16; Koekemoer 2007: 75; Mahieu 1975: 236; Pechuël-Loesche 1907: 135; Schwab 1947: 413; Sicard 1966: 42), samuti Indoneesia lääneosas ja Malaisias, eriti mentawai, klemantani ja kayani hõimude seas (Hose \& McDougall 1912: 142, 214; Schefold 1988: 71; Skeat \& Blagden 1900: 5) ning Lõuna-Hiinas miaode hulgas (Its 1960: 107). Kujutelm tähtedest kui taevaaukudest on siiski rohkem levinud Põhja-Euraasias, Põhja-Ameerika arktilistel aladel ja võimalik, et Borneol (Joonis 2). Erandjuhtudel on seda kujutelma

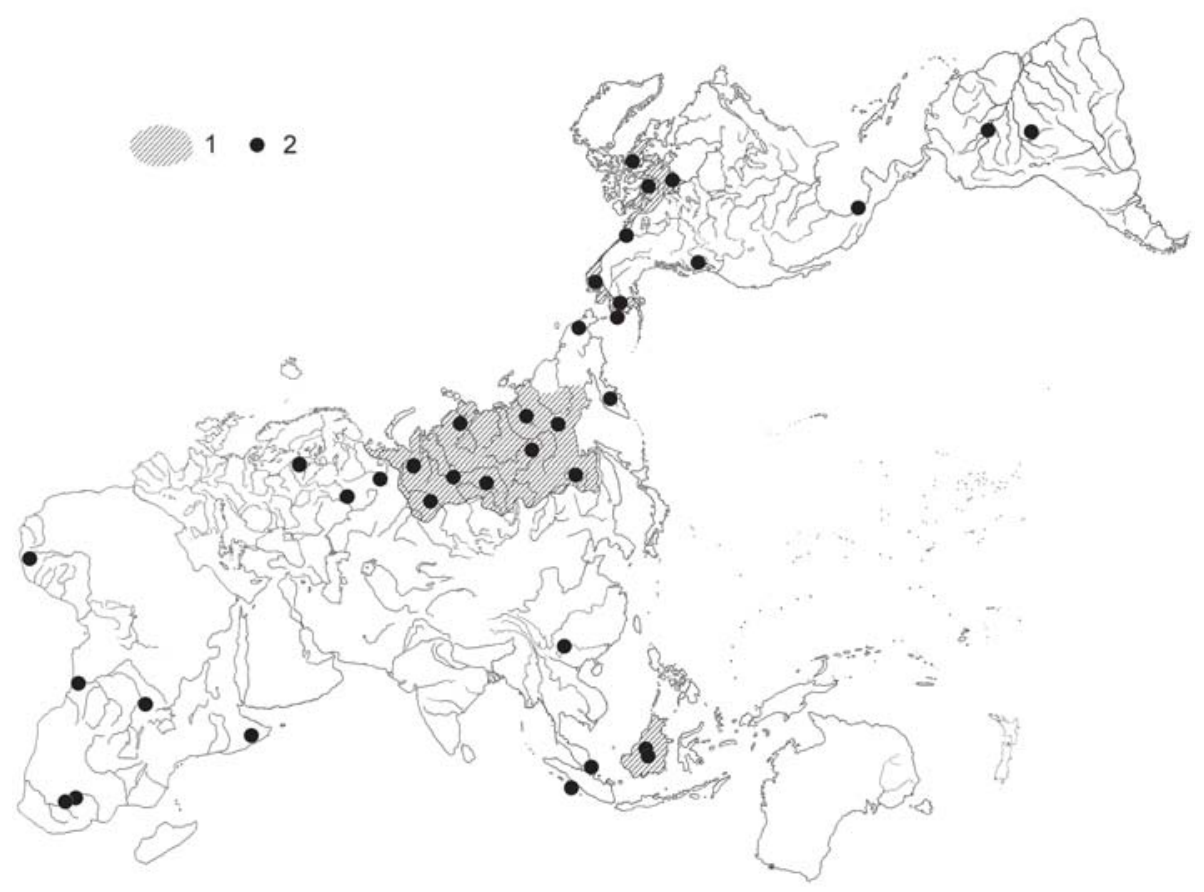

Joonis 2. Levikukaart tähtede tõlgendamisest aukudena taevavõlvis. 1 - tähistatud tõenäoliselt pidev levik, 2 - tähistatud paigad, mille kohta on saadud andmeid. 
talletatud eestlastelt (Kuperjanov 2003:125), maridelt (Aktsorin 1991, nr 26 : 59-60), komidelt (Ariste 2005, nr 136: 163), samuti paistab see olevat omane neenetsitele (Nenjang 1997: 214, 224; Helimski 1982: 399), nganassaanidele (Popov 1984: 45; Simtšenko 1996: 191), hantidele (Lukina 1990, nr 8: 67-69), ketidele (Aleksejenko 1976: 79; Dulzon 1966: 15-17; 1972: 83-86), jakuutidele (Gurvitš 1977: 199; Ergis 1967: 134), evenkidele (Vassiljevitš 1959: 161-162; Voskoboinikov 1960: 296), eveenidele (lamuutidele) (Burõkin 2001: 114) ja negidaalidele (Pevnov 2008). Samalaadset kaudset ja ebamäärast teavet leidub veel tšuktšide ja kamtšadaalide kohta (Ergis 1974: 134; Jochelson 1961: 71-74). Põhja-Ameerikas on taevaaukude kujutelm tunnuslik arktilistel aladel, kus seda on jäädvustatud kesk-jupikidelt, sh Nunivaki saarelt, inupiakidelt, Mackenzie delta, Põdrajärve (Caribou), Netsliki ja Iglooliki inuitidelt (Lantis 1946: 197; MacDonald 1998: 33; Nelson 1899: 495; Ostermann 1952: 56, 58; 1952: 128; Rasmussen 1930: 79). Siinjuures tuleks silmas pidada hüpoteesi, mille järgi inuitide põlvnemine lahkneb Ameerika põliselanike päritolust. Kujutelm kindlast tähest (tavaliselt Põhjanaelast) kui taevaaugust, läbi mille pääseb ülemisse ilma, on teada paljudel Ameerika indiaanlastel, kuid üldine ettekujutus tähtedest kui avaustest taevavõlvis on nii Lõuna- kui ka PõhjaAmeerikas kirjutatud üles vaid üksikutel juhtudel ja eraldatud hõimudelt, nagu Thompsoni jõe sališid, totonakid, tukunad ja tuparid (Boas 1895, nr 4: 17-18; Caspar 1975: 188; Ichon 1969: 36; Nimuendaju 1952: 123-124). Rõhuv enamus Ameerika põliselanikest, aga ka Aafrika, Austraalia, Okeaania ja Aasia India ja Vaikse ookeani ääremaade rahvad on suhtunud tähtedesse kui kindlat tüüpi taevakehadesse vaid teatud kindlal moel, st käsitades neid isikute, vaimolendite või mingite elusolenditena.

\section{Linnutee kui rändlindude rada}

Teine kosmonüüm, mille leviku läänepiir kattub enamjaolt leedulaste ja poolakate vahelise piiriga, on Linnutee nimetamine Lindude Rajaks (Joonis 3) või täpsemalt hanede, partide, luikede või kurgede järgi Rändlindude Rajaks. Uurijad on mõnikord seostanud Linnuteed üldisemalt surnute teega (Kuperjanov 2001). Need kaks kujutelma on tähenduselt üsna sarnased (Azimov \& Tolstoi 1995: 118), kuid kosmonüüm Linnutee on siiski üsna eripärane ja esineb vahel koos konkreetse surnute tee kujutelmaga (Aihenwald jt 1982: 164). Selle kosmonüümi levikuala kattub vaid osaliselt piirkonnaga, kus lindude ränne kajastub rahvatraditsioonides. Viimast esineb laialdaselt nt mõnede Alaska ja PõhjaAmeerika loodealade põliselanike ja Lõuna-Ameerika indiaanlaste seas (Berezkin 2007), kuid Linnutee on enamikule tundmatu. 


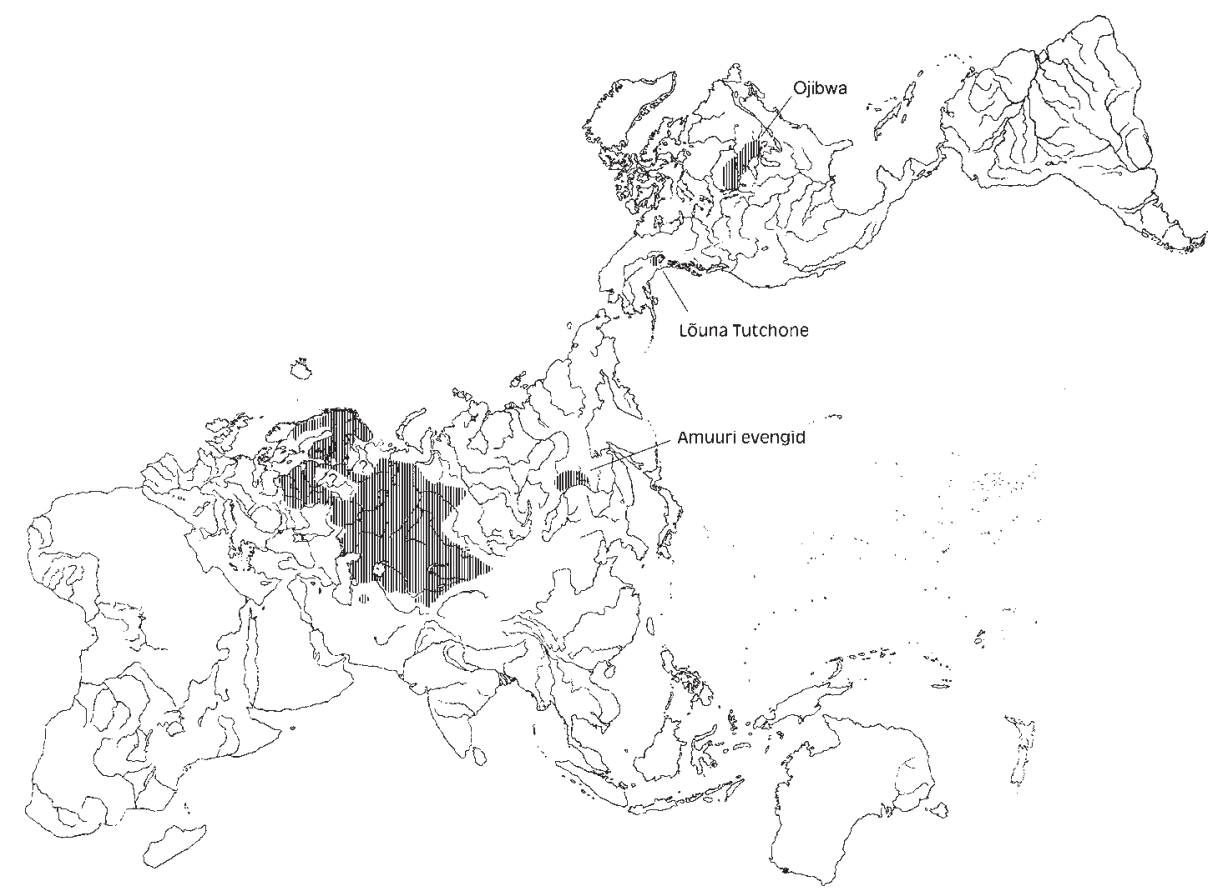

Joonis 3. Levikukaart paikadest, kus Linnuteed tõlgendatakse Rändlindude Teena.

Linnutee (Kuretee, Lindude Rada, Linnutee Jälg jt) on tuntud peamiselt kolme keelkonda kuuluvatel rahvastel - baltlastel, soomeugrilastel (v.a samojeedi keeltes) ja türgi rahvastel. Nende hulka kuuluvad lätlased ja leedulased (Kerbelyte 2001: 57; Gładyszowa 1960: 77-78; Vaiškūnas 1999: 173), liivlased (Toivonen 1937: 123), eestlased (Pustõlnik 2002: 268; Kuperjanov 2003: 150151), soomlased (Erdödi 1968: 110-111), saamid (Erdödi 1968: 111; Toivonen 1937: 123), marid (Aktsorin 1991: 55-56; Erdödi 1968: 110; Vassiljev 1907: 12), mordvalased (Devjatkina 1998: 118), tšuvašid (Ašmarin 1984: 26; Rodionov 1982: 168; Zolotnitski 1874: 22), Volga tatarlased (Vorobjov \& Hissamutdinov 1967: 316), baškiirid (Barag 1987: 33; Rudenko 1955: 315), udmurdid (Erdödi 1968: 110; Moškov 1900: 197; Potanin 1883: 740; Vereštšagin 1995: 81), komid (Erdödi 1968: 110; Napolskihh 1992: 6; Potanin 1883: 943), kasahhid (Karuts 1911: 35; Potanin 1881: 126-127; Sidelnikov 1962: 268), kirgiisid (Abramzon 1946: 65; Fielstrup 2002: 217, 227; Potanin 1881: 127) ja karakalpakid (Nikonov 1980a: 248). Turkmeenidel säilis Linnutee kosmonüüm kuni 19. sajandi keskpaigani (Nikonov 1980a: 248; 1980b: 293). Sama kosmonüümi kasutasid handid ja mansid (Erdödi 1968: 109-110; Munkácsi 1908: 254; Napolskihh 1992: 8) ja kuni 16. sa- 
jandini ka ungarlased (Nikonov 1980a: 248), kes tõid selle tõenäoliselt kaasa oma idapoolselt kodumaalt. Teine nimetus Linnutee kohta on obiugrilaste seas levinud nimetus Suusatee, mis on seotud taevase põdra jahti kirjeldava müüdiga (Erdödi 1968: 116). Viimane on kas ainus või siis peamine nimetus samojeedi keeltes ning Ida-Siberi, Amuuri alamjooksu ja Alaska rahvastel. Obiugrilastel esinevad küll mõlemad nimetused, kuid need on seotud erinevate mütoloogiliste kujutelmade tsüklitega.

Vologda, Vjatka, Permi, Tuula, Smolenski ja Kaluuga oblastis ja Siberis elavad venelased nimetavad Linnuteed Haneteeks (Gura 1997: 671; Rut 1987: 13), samuti kasutatavad seda nime Pinski lähistel elavad Polesje valgevenelased (Gura 1997: 658) ja Lutski lähedal elavad Volõõnia ukrainlased (Tšubinski 1872: 15; Moškov 1900: 205). Venemaa lõunaosas, peamiselt Ukrainas ja lõunapoolsetel slaavlastel seda kosmonüümi ei esine. Kosmonüümi geograafiline levik viitab, et see on slaavlaste laen soome-ugri või balti substraadist, mis lõpuks viib meid sama kultuuriderühmani, kes nimetavad Plejaade Taevasõelaks. Samas pole Sõela ja Linnutee geograafilise leviku kattumine täielik, kuna viimase kosmonüümi levikuala on veelgi laiem. Sinna on oluline lisada nii saamid kui ka Volga jõe piirkonnast teisel pool elavad türgi rahvad, st kasahhid, kirgiisid, karakalpakid ja turkmeenid. Siiski ei esine seda kosmonüümi ka kõigil türgi rahvastel. Linnutee puudumine Sajaani-Altai piirkonna rahvastel, aga ka usbekkidel (ja väga tõenäoliselt uiguuridel) muudavad selle kosmonüümi proto-türgi päritolu kaheldavaks.

Siiski tuntakse Linnuteed Amuuri keskjooksu evenkide (Vassiljevitš 1969: 210) ja Suurest Järvistust põhja pool elavate algonkini hõimude, eriti aga odžibvede (ojibwa) seas, sh kaks Huroni järve lähedal elavat hõimu (Miller 1997: 60; Speck 1915: 79) ja Saulteaux' indiaanlased (Hallowell 1934: 394). Pole kindel, kas Alaska lõunapiiri äärses Kanadas elavatest atapaski (Tutchone Athabascan) hõimudest kõnelevad allikad on seotud sama kujutelmaga. Lõunapoolsetel tutchonedel tähistab Linnutee pimeda küti terveks ravinud kauri lennuteekonda (McClelland 1975: 78).

Linnutee kosmonüümi levik tervikuna ei õigusta selle kosmonüümi Balti või Türgi algupära. Arvatavasti tundsid soomeugrilased Linnuteed juba ammustel aegadel, kuid kosmonüümi puudumine samojeedidel muudab selle proto-Uurali päritolu küsitavaks. Teisalt pidi see nimetus olema tuntud Euroopas juba kaua enne proto-uurali keele lahknemist kaheks suureks haruks, kui mitte arvestada, et see võis tekkida iseseisvalt evenkidel ja algonkini hõimul. 


\section{Veekandja Kuul}

Kolmandaks kosmonüümiks, mille läänepoolne piir Euroopas kattub üldjoontes baltlaste ja slaavlaste vahelise piirjoonega, on veekandja Kuul (Joonis 4). Laiemalt on levinud kaks seda motiivi sisaldavat lugu. Neist esimene jutustab sellest, kuidas Kuu halastab vett tooma saadetud vaeslapsele, vaesele võõrastütrele vm sarnasele tegelasele ja võtab ta enda juurde. Teise jutu järgi võtab Kuu karistuseks enese juurde üleolevalt või hooplevalt käitunud tüdruku või neiu. Sestsaadik võib Kuul näha kaelakookudega neiu kujutist. Baltlastelt ja läänemeresoomlastelt, eriti aga leedulastelt (Kerbelyte 2001: 70; Laurinkene 2002: 365; Vaiškūnas 2006: 158), liivlastelt (Loorits 2000: 318), eestlastelt (Kuperjanov 2003: 72; Peebo \& Peegel 1989: 282; Jüvä jt 1995: 94) ja vadjalastelt (Ariste 1974: 5; 1977: 175; Ernits \& Ernits 1978: 579) on talletatud üks või mõlemad jutuvariandid, lisaks harvem esinevaid seletusi. Näiteks karjalastel kannab tütarlaps käes piimapange (Jevsejev 1981: 129). Vepslastel pole selle muistendi kohta andmeid (Jegorov 2003: 129). Saamidel võtab Päike neiu enda juurde, et anda ta pojale naiseks, ja heidab neiu Kuu peale, kus teda võib

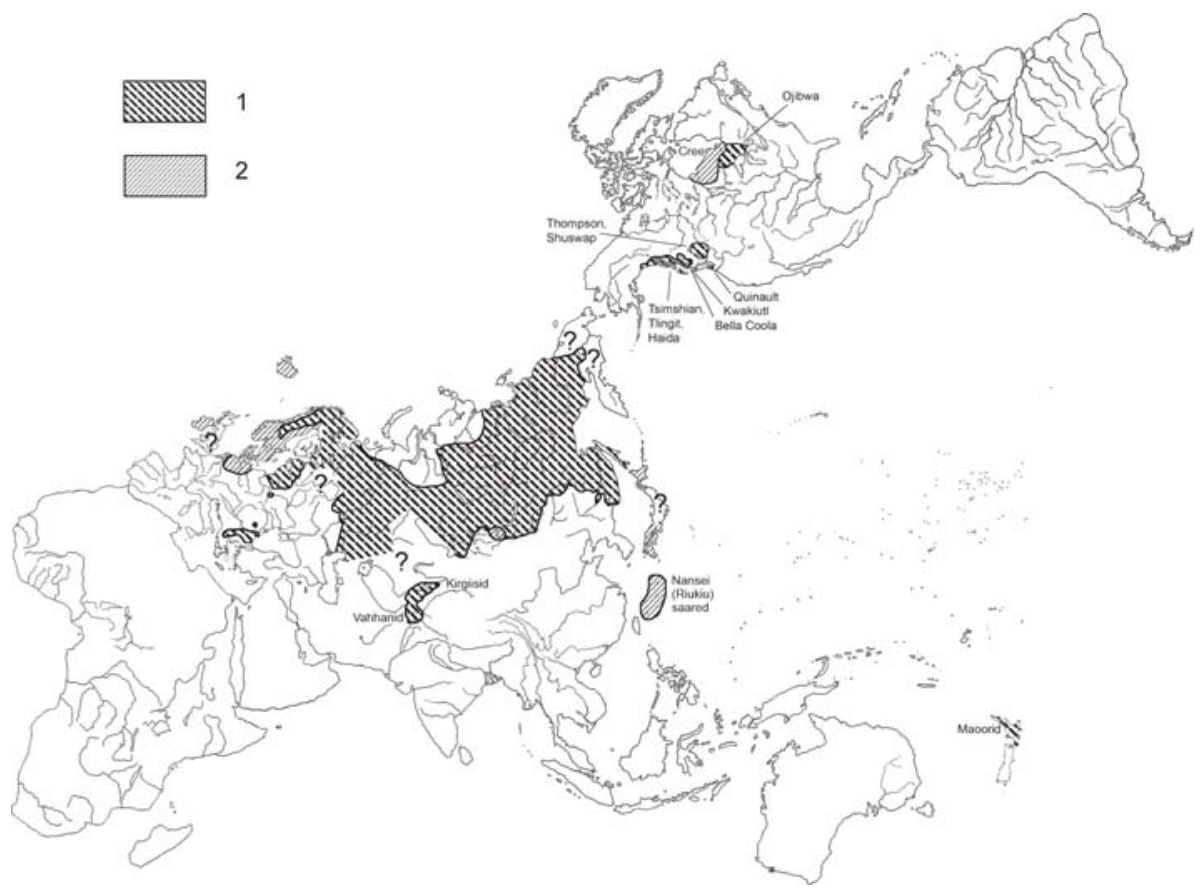

Joonis 4. Levikukaart Kuu tumedate laikude tõlgendamisest pange hoidva veekandja kujutisena Kuul. 1 - tüdruk või noor naine, 2 - kaks last, väike poiss, noormees või mees. 
pangede ja kaelakookudega tänaseni näha (Tšarnolusski 1962: 68-79). VolgaPermi piirkonnas teavad veekandjat Kuul sürjakomid (Ariste 2005, nr 109: 105; Limerov 2005, nr 58: 55-56), permi-komid (Konakov jt 2003: 312), udmurdid (Potanin 1883: 776; Vereštšagin 1995: 85-86; Vladõkin 1994: 322), tšuvaššid (Ašmarin 1984: 25; Denisov 1959: 15-16; Vardugin 1996: 260; Jegorov 1995: 120), marid (Aktsorin 1991, nr 37-42: 83-87; Moškov 1900: 197), baškiirid (Nadršina 1985, nr 6, 7: 12 13; Rudenko 1955: 315), samuti Volga tatarlased (Vorobjov \& Hissamutdinov 1967: 314-315). Nendel aladel on vaeslapse motiiv laialt tuntud, siiski puudub täielikult variant Kuud pilkavast naisest. Baškiiridelt ja tatarlastelt on talletatud lugu Kuust, kes viis neiu kaasa, kuna oli temasse armunud. Nagu Sõela kosmonüümi puhul, moodustavad mordvalased siingi erandi - nimelt puudub mordva traditsioonis motiiv veekandja Kuul. Venelastel on vaeslapsest veekandja motiiv teada vaid Vjatka oblastis (Belova 2004, nr 1305: 521), samas kui Arhangelski oblastist on üles kirjutatud motiiv noormehest ja neiust, kes läksid vett tooma ja jäid liiga pikalt Kuud vaatama (Gura 2006: 262). Need põhjapoolsete venelaste kohta käivad andmed pole kaugeltki täielikud, kuna see osa piirkondlikest kosmonüümidest pole kunagi olnud uurimiskeskmes. Ukrainas on kosmonüümi Veekandja Kuul talletatud ainsana Volõõnia piirkonnas (Gura 2006: 262) - paigas, kus tuntakse ka Linnutee kosmonüümi.

Nagu Linnutee, oli ka vaese võõrastütre motiiviga veekandja Kuul teada kirgiisidele (Brudnõi \& Ešmambetov 1968: 11-13) ja kasahhidele. Kasahhide vastav materjal koguti hiljaaegu Aktöbe oblastist (Stasevitš 2006). Kasahhide uskumusi Kuu tumedatest laikudest pole varem uuritud, seega on andmete puudumine idapoolsetel kasahhidel ja karakalpakkidel suhteliselt vähetähtis. Kirgiisidelt võis vett tooma saadetud ja üles Kuu juurde võetud vaese võõrastütre motiiv levida Pamiiri aladele, kus see on teada vähemalt vahhanitel (Laškarbekov 2005). Veekandjat Kuul on kahes variandis (vaene võõrastütar ja kõlvatu naine) talletatud ka Siberi tatarlastelt (Valejev 1976: 329; Urazalejev 2007: 4). Seda motiivi ei tunne põhja-samojeedid ega põhjapoolsed sölkupid. Lõunapoolsed sölkupid uskusid, et vett saadeti tooma väike tüdruk või siis et Kuud pilkas noor neiu (Golovnev 1995: 330-331; Pelihh 322-323). Hantidel oli Kuu pilkajaks väike tüdruk (mõnes variandis koos poisiga) (Kulemzin \& Lukina 1978, nr 4, 5: 15-16) ja mansidel kaelakookudega neiud, kuigi lähemad selgitused selle motiivi kohta puuduvad (Ivanova 2009).

Ketidel narritas Kuud noor tütarlaps või naine (Aleksejenko 1976: 84). Hakassidel, samuti kirgiisidel ja kasahhidel (Butanajev 1975: 232) oli üldlevinud sama lugu vaesest võõrastütrest. Altai piirkonnas pole see motiiv üldtuntud. Vaid üks paljudest juttudest, kus kirjeldatakse, kuidas hiiglane Tilbegen 
(Jelbegen vmt) pääses Kuule, räägib sellest, kuidas Kuu võttis ta üles enda juurde just siis, kui ta oli kaelakookude ja pangedega vett tooma läinud (Anohhin 1997: 5-5).

Andmed šoride ja tõvalaste kohta puuduvad, kuid tofadel jõudis Kuule hoopis vett tooma saadetud vaene poisslaps (Rassadin $1996 \mathrm{nr}$ 3: 10). Mongoolias Hövsgöli järve ääres elavate darhaatide legendis läksid kaks poissi vett tooma ja sattusid Kuu peale (Nekljudov jt 2007). Üles on kirjutatud kolm sarnase süžeega teksti, millest üks pärineb informandilt, kelle vanemad olid Halha mongolid, kuid elasid Hövsgöli aimaki darhaatide seas. Teistes Mongoolia piirkondades seda motiivi ei tunta ja seega näib, et see oli seotud vaid Siberi, mitte Kesk-Aasiaga. Hövsgöli darhaadid võtsid üsna hiljuti üle mongoli keele ja nende kultuur on sarnane Todža tõvalaste omale (Žukovskaja 1988: 151). 20. sajandi alguses kasutasid darhaadi šamaanid vaimude poole pöördumisel endiselt tõva keelt (Sanžejev 1930: 7).

Näib, et erinevad burjaadi hõimud on mongolieelsest substraadist üle võtnud nimetuse Veekandja Kuul. Nendelt hõimudelt on mitmel korral seda lugu üles kirjutatud vaese võõrastütre loo sarnaselt: võõrasema või uuesti mehele läinud lihane ema saadab neiu vett tooma ja soovib, et Kuu võtaks ta enda juurde (Galdanova 1987: 17; Hangalov 1958: 319; 1960: 14; Potanin 1883: 190_ 193; Šarakšinova 1980: 49-50). Mitmed jakuudi hõimud (Aleksejev jt 1995: 197-199; Gurvitš 1948: 130; 1977: 199; Hudjakov 1969: 279, 372-373; Ovtšinnikov 1897, nr 5-6: 179-181; Popov 1949: 260-261; Seroševski 1896: 667; Tolokonski 1914: 89), evengid (Potanin 1893: 385; Rõtškov 1922: 83-84; Vassiljevitš 1936: 73-74; 1959: 165; Voskoboinikov 1967: 159) ja lamuudid (Novikova 1987: 4344) tunnevad veekandjat Kuul vaese võõrastütre versioonis, kuigi üksikutel juhtudel on talletatud ka Kuud vaadanud ja selle juurde tõmmatud kahe lapse motiivi (Hudjakov 1969: 279). Evenkide vaese võõrastütre motiivile sarnane veekandja Kuul variant on teada ka negidaalide (Hassanova \& Pevnov 2003: 55-56; Lopatin 1922: 330) ja nanaide (Arsenjev 1995: 152; Tšadajeva 1990: 3435; Lopatin 1922: 330), kuid mitte Primorje ja Sahhalini rahvaste hulgas. See viitab asjaolule, et selles piirkonnas on motiiv seotud tunguusidega, aga mitte tunguusieelse substraadiga. Konkreetsemalt tunnevad nivhid vaese võõrastütre motiivi, kuid see on üles kirjutatud üsna hiljuti (Turajev 2008: 186) ja puudub Sternbergi või Kreinovitši materjalides, nii ei saa välistada selle hilist laenamist tunguusi hõimudelt. Samasugune pange või toobrit kandva neiu või naise kujutis Kuul on teada udehedele (Podmaskin 1991, nr 17: 125) ja seda on 20. sajandi algul üles kirjutatud nivhidelt (Ishida 1998: 24; Kreinovitš 1973: 32-33). Sahhalini ja Hokkaido ainud usuvad Kuul nägevat neidu, kes läks vett tooma ja kelle Kuu võttis üles endale naiseks (Pilsudski 1912 nr 3: 73-74; 1991 nr 3: 70-72), või kes kadedusest solvas Kuud, süüdistades teda laiskuses (Ishida 
1998: 24-25). Teise variandina on ainud näinud kuukettal poissi, kes samal moel Kuud solvas (Batchelor 1927: 260). Motiiv naisest Kuul, kes hoiab käes pangesid (täpsemate üksikasjadeta), on teada Lõuna-Jaapanis (Inoui 2005), samas kui Nansei saartelt (Miyako ja Okinawa) üles kirjutatud müüdid kirjeldavad, kuidas Kuule sattus veepangega mees (Nevski 1996: 267-269). Kirde-Aasiast on vaese võõrastütre varianti veekandjast Kuul kirjutatud üles jukagiiridelt (Nikolajeva jt $1989 \mathrm{nr} 2:$ 21-23) ja vene keelt kõnelevate Markovo küla elanikelt, kelle esivanemate hulgas on ka jukagiirid (tšuvanid) (Hakkarainen 2000). Veekandjat ei tunne paleoaasia rahvad, kuigi tšuktšidel (Bogoras 1939: 22-23; Bogoras 1928 nr 2: 301-302), korjakkidel (Beretti 1929: 36) ja kamtšadaalidel (Porotov \& Kossõgin 1969: 33) on teada vähem tüüpiline motiiv Kuule sattunud neiust.

Hakassidelt, tofadelt, burjaatidelt, ketidelt, sölkuppidelt, hantidelt, jakuutidelt ja kagu-evenkidelt üles kirjutatud tekstides esineb väga eripärane ja Siberile tüüpiline detail. Kui veekandja (mees või naine) võeti üles Kuule, püüdis ta end põõsast haarates kinni hoida ja nüüd võib teda kuukettal näha hoidmas nii pangesid kui ka põosast. Sama element on teada ka Pamiiri vahhanitel ja korjakkidel. Korjaki legendis (Beretti 1929: 36) ei mainita pangesid, kuid stseen tütarlapse saatmisest vee järele kurja võõrasema poolt on üldiselt sarnane jakuudi ja evengi variantidele. Lõuna-Siberi teleuutidel, altailastel ja hakassidel pole see motiiv seotud veekandjaga, seal üritas Kuu peale tõmbamisest pääseda põõsast haaranud hiiglane.

Üldjoontes võib öelda, et vett tooma saadetud tütarlapse või noore neiu motiiv on levinud laialdaselt kõikjal Euraasias Ida-Balti aladelt Ohhoota mereni. Sellega piirnevatel aladel leidub nii selliseid variante, kus mistahes tegelase veetoomise motiiv on unustatud või on neiu asemel tegelasteks poiss, mees või kaks last. Mitte kusagil mujal selles perifeerses piirkonnas (v.a korjakkidel) ei võta Kuu veetoojat enda juurde üles taevasse seetõttu, et tal temast kahju on. Lisaks mongoli, jaapani ja paleoaasia variantidele tuleb perifeersete kultuuride juures nimetada ka Skandinaavia ja Lääne-Euroopa omi. Iirimaal arvati nägevat Kuul kaht poissi, kes kannavad saua otsas veepange (Krappe 1938: 120), samas kui Põhja-Saksamaal oli tegu veekannu kandva mehega, pange kandva lapsega, kaht varastatud veepange kandva vargaga või kahe kaelakookude ja veetoobritega mehega (Ishida 1998: 20-21; Krappe 1940: 168; Wolf 1929: 55-56). Ka Skandinaavias nähti Kuu peal kaht kaelakookude ja pangedega last (Noorem Edda 1970: 20) või kaht vanameest, kes üritasid Kuud vette uputada (Krappe 1938: 120).

Eriti huvitav on asjaolu, et Euraasiast väljaspool salvestatud tekstid sarnanevad tüüpilisele Euraasia variandile, milles esineb motiiv Kuud solvanud 
naisest. Eriti hästi on veekandja Kuul teada enamikule rahvastele Põhja-Ameerika loodealadel ja sellega külgnevas Fraseri jõgikonnas.

Tlingitid. Üks kahest tüdrukust räägib, et Kuu näeb välja nagu ta vanaema huulerõngas. Silmapilk leiavad tüdrukud end Kuu pealt. Kuud pilganud tüdruk kukub maa peale tükkideks, kuid ta sõpra võib nüüd näha kuukettal pange hoidmas (Swanton 1908b: 453).

Haidad. Naine läheb vee järele ja näitab näpuga Kuu peale, siis kujutleb kedagi kaevus istumas ja osutab sellele kujutisele. Kui ta öösel janusena kaevule naaseb, haarab keegi tal käest ja tõmbab ülespoole. Naine püüab kinni hoida talihalja põõsast ja nüüd võib teda näha Kuul põõsast ja pange kandmas (Swanton 1908a: 450-452).

Nessi jõe tšimšid. Naine näitab näpuga Kuu peale ja siis selle peegeldusele vees. Kuu võtab ta enda juurde taevasse, kui naine on parajasti haaranud marjapõõsast. Nüüd võib näha teda Kuu peal, käes põõsas ja pang (Boas 1916: 864).

Bella Coola indiaanlased. Kuul nähakse naist, kes kannab käes veepange (McIlwraith 1948: 225).

Uvekeeno (oowekeeno). Väike poiss nutab ja ta õde tõstab ta õue ja annab mängimiseks kaasa ämbrikese. Poiss nutab endiselt, nii et õde hoiatab, et kui ta ei jäta, viib Kuu ta endaga kaasa. Kuu laskub taevast alla ja võtab poisi enda juurde ja nüüd võib teda näha Kuu peal väikest pange hoidmas (Boas 1895: 217; 2002: 457).

Kvahkeeolthid (kwakiutl, newetee). Kuu laskub maa peale ja küsib vett. Tüdruk läheb pangega õue ja Kuu röövib ta endale. Kui Kuu tuleb maa peale järgmist tüdrukut endaga viima, hoiatab esimese tüdruku ema teda ohu eest, kuid ka tema tuleb veepangega välja ja on nüüd, kaks pange käes, Kuu peal näha (Boas 1895: 191; 2002: 409).

Šusvaapid (shuswap). Talviti rändavat Kuu pidevalt ringi. Ta naine küsib, kus nad ööd veedavad. Kuu teeb ettepaneku, et naine jääks ööseks tema näole. Naine hüppab Kuu näole ja on seal seniajani näha, lumesulatamiseks mõeldud ämbrid ja labidas käes (Teit 1909: 653).

Thompsoni jõe sališid. Kuu saadab oma õe vett tooma. Tagasi jõudes ei leia viimane enam istekohta ja Kuu soovitab, et õde istuks talle näo peale. Nüüd on Kuu peal näha pangesid kandev naine (Teit 1898: 91-92). 
Quinault' indiaanlased. Kuu paistis heledalt nagu päike. Paljud neiud ihkasid teda endale, kuid Kuu valis konna. Nüüd võib kuukettal näha konn-naist, kes hoiab käes varalaegast ja pange (Thompson \& Egesdal 2008: 207-209).

Kolmes viimases tekstis on loodealade hõimudele omane veekandja motiiv põimunud sališitele iseloomuliku motiiviga tegelasest (enamasti konn-naine), kes klammerdub Kuu näole ja on tumedate laikudena sel moel Kuul tänaseni nähtav.

Loodealadest kaugemal on veekandja motiiv talletatud Suurest Järvistust põhja pool asuvatelt algonkinitelt. Põhja-Ojibwa (Sandy järv) legendis hoiatab ema poega vett tooma saates, et too ei vaataks Kuu poole. Poiss aga kadus, ja nüüd võib teda näha Kuul, käes kopsik ja ämber (Ray \& Stevens 1971: 81). Sellest loost teatakse kriide (Swamp Cree) seas eri variante, mõnel puhul ei hoiatanud teda ema vaid vanem õde (Bird 2007: 36-37; Clay 1978: 28-33; Ellis 1995: 23-27, 29-33, 119). Ülemjärvest põhja pool elavate odžibvede (ojibwa) legendis keedab naine vahtrasiirupit ja kallab seda ühest pangest teise. Kuu näeb naist sealsamas urineerimas - ta tunneb end solvatuna ja võtab naise üles taevasse. Päike, Kuu abikaasa, saab sellest teada ja sunnib oma naist karistuseks taevassevõetut igavesti kaasas kandma. Nii võibki nüüd Kuul näha pangega naist (Jones 1919: 637).

Veekandja Kuul on tuttav ka Uus-Meremaa maooridele. Niipea, kui Hina asus oma pudelkõrvitsast anumaga vett ammutama, peitis Kuu end pilvede taha. Hina komistas ja vesi voolas maha. Hina kurjustas Kuuga, Kuu aga haaras temast ja Hina klammerdus põõsa külge. Nüüd võib teda Kuul näha hoidmas põõsast ja pudelkõrvitsat (Ishida 1998: 26). Teises variandis sattus Kuu peale Rona-nimeline mees (Reed 1999, nr 16: 190-192). Veel järgmises variandis on Rona naisenimi (Dixon 1916: 87-88). Paistab, et kõige levinum variant oli see, kus Kuule sattus naistegelane. Selle legendi kohta võib leida mittetäielikke paralleele teisteltki Polüneesia saartelt, samuti nähakse Kuul ka veeanumaid (Beckwith 1970: 220-221; Dixon 1916: 88; Williamson 1933: 100). Kuigi Uus-Meremaa jääb Siberist väga kaugele, tuleks selle maoori legendi algallikaid otsida Ida-Aasiast, mis on tõenäoliselt Austroneesia algkodu, kuna midagi sarnast pole avastatud Melaneesiast ega Indoneesiast. Jõe äärde tulnud, põõsast kinni haaranud ja üles Kuu juurde tõmmatud naise motiiv seob maoori variandi kindlalt legendidega, mida on üles kirjutatud haidadelt, tšimšidelt ja paljudelt Siberi rahvastelt. Arvamus, et sedavõrd iseloomulike elementidega lood levisid koos eurooplaste rändega või et need lood tekkisid iseseisvalt ja sõltumatult, oleks põhjendamatu. 


\section{Kokkuvõtteks}

Eespool kirjeldatud kolme kosmonüümi levialad kattuvad suures osas. Levikujooned on põhimõtteliselt järgmised. Kõik kolm motiivi on iseloomulikud IdaBalti ja Kesk-Volga aladele. Neist kolmest kahe puhul (Plejaadid Taevasõelana ja veekandja Kuul) on vaid lõunapoolsed Kesk-Volga rahvad (st mordvalased) selles piirkonnas ainsad, kelle puhul puuduvad andmed nende motiivide esinemise kohta. Kõik motiivid on iseloomulikud mõnele või isegi paljudele Venemaa põhjapoolsetele oblastitele, kuid tundmatud Venemaa lõunaosas või Ukrainas, v.a väike asulasala Volõõnias. Pole kahtlust, et motiivid jõudsid idaslaavlasteni mingist palju varasemast substraadist. Põhjapoolsed samojeedid (neenetsid, neenetsid ja nganassaanid) neid motiive ei tunne ja sölkuppidele on teada vaid üks - veekandja Kuul. Linnuteed tunnevad kõik soomeugrilased ning peale mordvalaste ja ungarlaste on enamikule neist tuttav ka veekandja Kuul. Kosmonüüme Linnutee ja Veekandja Kuul tuntakse kasahhide ja kirgiiside juures, samas kui Altai-Sajaani türklastel need puuduvad. Keskmise hordi kasahhidelt on talletatud Sõela vaid Plejaadide tähistamiseks. Jenissei jõest ida pool on laiemalt levinud vaid motiiv veekandja Kuul, mida on korduvalt üles kirjutatud jakuutidelt, evenkidelt ja burjaatidelt. Isegi kui pidada Sõela (Plejaadide nimetusena) taevaavade motiivi erivariandiks, on ikkagi täheldatav seos Ida-Euroopa ja Siberi vahel. Lisaks tundsid Linnuteed ka Amuuri evengid. Suurest Järvistust põhja poole jäävad algonkinid teavad nii Linnuteed kui ka veekandjat Kuul, samuti võimalikku kujutlust Plejaadidest kui taevaavadest. Veekandja Kuul on veel omane Loodealade põlisrahvastele ja Loodealade lõunaosa ja madaliku põhjaosa sališite seas. Kui arvestada, et sellised motiivid puuduvad täielikult sališitest ja odžibvedest kaugemal lõunas asuvate Ameerika põlisrahvaste juures, võib nende Siberi päritolu pidada täiesti võimalikuks. Kui see nii on, tuleks nende motiivide levik Euraasias dateerida veel kaugemasse perioodi, vähemalt varasesse holotseeni ajastikku.

Jää sulades liikus asustus peamiselt lõuna poolt Ida-Euroopa põhjapoolsetele aladele. Arheoloogid on kindlaks määranud, et Baltimaade idaosas tekkisid esimesed jääajajärgsed kultuurid hilispaleoliitikumi Swidry kultuuri ajal seda järeldust toetavad nii kranioloogilised kui ka populatsioonigeneetika andmed (Niskanen 2002: 144-147). Sellesse kuvandisse sobib ka teatud mütoloogiliste motiivide levik (Napolskihh 1990). Siiski viitavad ülalkirjeldatud motiivide levikumustrid sellele, et mingil määral imbus neid sisse ka ida poolt. Isegi kui jätta kõrvale evenkide ja algonkinite andmed Linnutee kohta ja pidada tähtede kui taevaavade motiivi väheoluliseks, näib motiivi veekandja Kuul levikumuster tegevat Euraasia-ülese leviku üsna usutavaks. Meenutades 
detailseid Ida- ja Lõuna-Siberi variantide Ameerika ja Polüneesia paralleele, võiks pidada selle motiivi varaseimaks levikuvööndiks pigem Põhja-Euraasia ida- kui lääneosa. Veekandja Kuul motiivi Bulgaaria-Makedoonia sulusala ei saa kahtlemata olla Siberi legendide algkodu, rääkimata indiaani ja Polüneesia legendidest; Bulgaaria materjalid viitavad pigem hilisematele Balti ja Balkani seostele.

Balkani rahvaste puhul tuleks veekandja motiivide päritolu tuvastamisel võrrelda Bulgaaria-Makedoonia materjale Serbia omadega. Kahjuks on Serbia tõlgendused Kuu tumedatest laikudest üsna hilist päritolu ja sisaldavad vaid neid variante, mida tuntakse terves kristlikus Euroopas (Jankovitš 1951: 108109). Üksnes Bulgaaria variantidele iseloomulikku motiivi (sellest, kuidas poiss ja tüdruk tulevad kaevule ja satuvad Kuule) teatakse veel vaid põhjapoolsete venelaste seas (Gura 2006: 462). Makedoonia variant (Kuu päästab õnnetu võórastütre, kes seisab nüüd kaht pange käes hoides Kuul) sarnaneb Leedu, Eesti ja Kesk-Volga variantidega.

On tõenäoline, et hilisest pleistotseenist varajase holotseenini hakkasid Põhja- ja Kesk-Euraasias kujunema juba konkreetsemad ettekujutused tähistaeva objektidest. Euraasiast toodi vastavad ettekujutused kaasa Põhja-Ameerikasse. Aasias, India ja Vaikse ookeani piirialadel, Austraalias, Lõuna- ja KeskAmeerikas arenes kosmonüümide teke sõltumatult ning puuduvad paralleelid Põhja-Euraasia ja Põhja-Ameerika motiivistiku ja süžeedega, samas kui Saharataguses Aafrikas oli selle areng minimaalne. Kuna Siberis ja Ida-Euroopas varasemad kujutelmad uute tulekuga ei kadunud ja hilisemad vaid täiendasid neid, oli väike ida poolt saabunud sisserändajate hõim tõenäoliselt piisav selleks, et uued kosmonüümid leviksid peaaegu üle terve Euraasia. Kui sisserändajad olid kütid ja kalastajad, siis oleks nende läänesuunalise rände loogiline piir olnud Läänemeri. Olen arvamusel, et just see on peamine põhjus, miks Ida-Balti piirkonna ja Kesk-Euroopa kosmonüümid üksteisest erinevad.

Tõlkinud Kait Tamm

Artikli valmimist toetas Venemaa Fundamentaaluuringute Fond (grant nr 07-06-00441-a) ja Venemaa Teaduste Akadeemia presiidiumi eriprogrammi "Venemaa ajaloolis-kultuuriline pärand ja vaimsed väärtused" projekt "Siberi varaseim asustamine ja ränne Uude Maailma”. 


\section{Kommentaarid}

Uurimuses kasutatud materjal on pärit maailma mütoloogia ja rahvaluule elektroonilisest kataloogist. Venekeelsete teeside ja tekstide allikatega on võimalik tutvuda veebis aadressil http://www.ruthenia.ru/folklore/berezkin. Mütoloogiliste motiivide ja motiivide levikukaardid on kättesaadavad aadressil http:// starling.rinet.ru/kozmin/tales/index.php?index=berezkin.

\section{Kirjandus}

Abramzon 1946 = Абрамзон, Саул. Очерк культуры киргийзского народа. Фрунзе: Изд-во КиргФАН СССР.

Aihenwald jt 1982 = Айхенвальд, Александра \& Петрухин, Владимир \& Хелимский, Евгени. $\mathrm{K}$ реконструкций мифологических представлений финно-угорских народов. Балто-славянские исследования 1981. Москва: Наука, lk 162-192.

Aktsorin 1991 = Акцорин, Виталий. Марийский фольклор. Мифы, легенды, предания. Йошкар-Ола: Марийское книжное издательство.

Aleksejenko 1976 = Алексеенко, Евгения. Представления кетов о мире. Природа и человек в религиозных представлениях народов Сибири и Севера. Ленинград: Наука, lk 67-105.

Aleksejev jt 1995 = Алексеев, Николай \& Емельянов, Николай \& Петров, Василий. Предания, легенды и мифы Саха (якутов). Новосибирск: Наука.

Allen, Richard H. 1899. Star-Names and Their Meanings. N.Y., Leipzig: G.E. Stechert. Andree, Richard 1878. Ethnographische Parallelen und Vergleiche. Stuttgart: Maier.

Anohhin 1997 = Анохин, Андрей. Легенды и мифы Седого Алтая. Горно-Алтайск: Министерство культуры республики Алтай..

Ariste, Paul 1974. Vadja muinasjutte ja muistendeid. Vääri, Eduard (vast toim). Töid eesti filoloogia alalt 4. Tartu: Tartu Riiklik Ülikool, lk 3-34.

Ariste, Paul 2005. Komi rahvaluulet. Kogunud Paul Ariste. Коми фольклор. Собрал П. Аристэ. Tartu: Eesti Kirjandusmuuseum.

Arsenjev 1995 = Арсеньев, Владимир. Из научного наследия В. К. Арсеньева. Краеведческий бюллетень общества изучения Сахалина и Курильских островов 4, lk 151-183.

Ašmarin 1984 = Ашмарин, Николай. Введение в курс чувашской народной словесности. Чебоксары: НИИ языка, литературы, истории и экономики при Совете Министров Чувашской АССР, lk 3-48.

Azimov \& Tolstoi 1995 = Азимов, Э. Г. \& Толстой, Никита. Астрономия народная. Толстой, Никита (toim). Славянские древности. Этнолингвистический словарь 1. Москва: Международные отношения, lk 117-119. 
Barag 1987 = Бараг, Лев. Башкирское народное творчество 2. Предания и легенды. Уфа: Башкирское книжное издательство.

Batchelor, John 1927. Ainu life and lore. Tokyo: Kyobunkwan.

Beckwith, Martha 1970. Hawaiian Mythology. Honolulu: University of Hawaii Press.

Belova 2004 = Белова, Ольга. “Народная Библия”: Восточнославянские этиологические легенды. Москва: Индрик.

Beretti 1929 = Беретти, Н. И. На крайнем Северо-востоке. Владивосток: Издание Владивостокского отдела Государственного Русского географического общества.

Berezkin, Juri 2006. The cosmic hunt: variants of a Siberian - North-American myth. Folklore. Electronic Journal of Folklore (Tartu) 31, lk 79-100 (http://www.folklore.ee/ folklore/vol31/berezkin.pdf - 30. oktoober 2010).

Berezkin, Juri 2007. Dwarfs and cranes. Baltic Finnish mythologies in Eurasian and American perspective (70 years after Yriö Toivonen). Folklore. Electronic Journal of Folklore (Tartu) 36, lk 75-96 (http://www.folklore.ee/folklore/vol36/berezkin.pdf - 30. oktoober 2010).

Bird, Louis 2007. The Spirit Lives in the Mind. Omushkego Stories, Lives, and Dreams. London \& Ithaca: McGill-Queenäs University Press.

Boas, Frans 1895. Indianische Sagen. Berlin: Asher.

Boas, Frans 1916. Tsimshian mythology. 31th Annual Report of the Bureau of American Ethnology. Washington: Smithsonian Institution, lk 29-1037.

Bogoras, Waldemar 1928. Chuckchee tales. Jornal of American Folklore 41, lk 297452 .

Bogoras 1939 = Богораз, Владимир. Чукчи 2. Религия. Ленинград: Изд-во Главсевморпути.

Boneva 1994 = Бонева, Таня 1994. Народен светоглед. Родопи. Традиционна духовна и социално-нормативна култура. София: Етнографски Институт с Музей, БАН, lk 750.

Brudnõi \& Ešmambetov 1968 = Брудный, Дмитрий \& Эшмамбетов, Касымбек. Киргизские народные сказки. Москва: Художественная литература.

Burõkin 2001 = Бурыкин, Алексей. Малые жанры эвенского фольклора. СанктПетербург: Петербургское востоковедение.

Butanajev 1975 = Бутанаев, Виктор. Представление о небесных светилах в фольклоре хакасов. Ученые записки Хакасского НИИ языка, литературы и истории. Серия филологическая 20 (3), lk 231-240.

Caspar, Franz 1975. Die Tuparí. Berlin, New York: de Gruyter.

Clay, Charles 1978. Swampy Cree Legends. Bewdley, Ontario: Pine Ridge Publications.

Denisov 1959 = Денисов, Петр. Религиозные верования чуваш. Историко-этнографические очерки. Чебоксары: Чувашское государственное издательство.

Devjatkina 1998 = Девяткина, Татьяна. Мифология мордвы. Саранск: гУП Красный Октябрь. 
Dixon, Ronald 1916. Oceanic Mythology. Boston: Marshall Jones.

Dolgihh 1961 = Долгих, Борис. Мифологические сказки и исторические предания энцев. Записи, введение и комментарии Б.О. Долгих. Москва: Изд-во АК СССР. Труды Института Этнографии им. Н.Н. Миклухо-Маклая.

Dulzon 1966 = Дульзон, Андрей. Кетские сказки. Томск: Изд-во Томского университета.

Dulzon 1972 = Дульзон, Андрей. Сказки народов сибирского севера. I. Томск: Издво Томского университета.

Dõbo, Anna 2008. Eravestlus.

Ellis, Douglas C. 1995. Cree Legends and Narratives from the West Coast of James Bay. Winnipeg: The University of Manitoba Press.

Erdödi, József 1968. Finnisch-Ugrische Gestirnnamen. Annales Universitatis Scientiarum Budapestiensis. Philologica 8, lk 105-121.

Ergis 1974 = Эргис, Георгий. Очерки по якутскому фольклору. Москва: Наука.

Ergis 1967 = Эргис, Георгий. Якутские сказки 2. Якутск: Якутское кн. изд-во.

Ernits, Tiiu \& Ernits, Enn 1984. Vadjalaste ja isurite tähelepanekuid taevakehade kohta. Eesti Loodus 9, lk 577-581.

Fielstrup 2002 = Фиельструп, Федор. Из обрядовой жизни киргизов начала XX века. Москва: Наука.

Galdanova 1987 = Галданова, Галина. Доламаистские верования бурят. Новосибирск: Наука.

Gamzatov \& Dalgat $1991=$ Гамзатов, Гаджи \& Далгат, Уздиат 1991. Традиционный фольклор народов Дагестана. Москва: Наука.

Gibbon, William 1964. Asiatic parallels in North American star lore: Milky Way, Pleiades, Orion. Journal of American Folklore 77 (305), lk 236-250.

Gibbon, William 1972. Asiatic parallels in North American star lore: Ursa Major. Journal of American Folklore 85 (337), lk 236-247.

Gładyszowa, Mária 1960. Wiedza ludowa o gwiazdoch [Rahvateadmised tähtedest]. Wroclaw: Zaklad narodovyim ossolińskich.

Golovnev 1995 = Головнев, Андрей. Говорящие культуры. Традиции самодийцев и угров. Екатеринбург: УрО РАН, Институт истории и археологии.

Gura 1997 = Гура, Александр. Символика животных в славянской народной традиции. Москва: Индрик.

Gura 2006 = Гура, Александр. Лунные пятна: способы конструирования мифологического текста. Славянский и балканский фольклор. Семантика и прагматика текста. Москва: Индрик, lk 460-484.

Gurvitš 1948 = Гурвич, Илья. Космогонические представления у населения Оленекского района. Советская этнография 3, lk 128-131.

Gurvitš 1977 = Гурвич, Илья. Культура северных якутов-оленеводов. Москва: Наука. 
Hakkarainen, Marina 1999. Intervjuu Juri Borissovitš Djatškoviga. Markovo, 02.06.1999. Euroopa Ülikooli arhiiv Peterburis.

Halidova 1984 = Халидова, М.Р. Фольклорные тексты. Примечания к фольклорным текстам. Халидова, M.P. (koost). Мифология народов Дагестана. Махачкала: Дагестанский филиал АН CCCP, lk 160-187.

Hallowell, A.Irving 1934. Some empirical aspects of northern Saulteaux religion. American Anthropologist 36, lk 389-404.

Hangalov 1958 = Хангалов, Матвей. Собрание сочинений 1. Улан-Удэ: Бурятское кн. изд-во.

Hangalov 1960 = Хангалов, Матвей. Собрание сочинений 3. Улан-Удэ: Бурятское кн. изд-во.

Harva, Uno 1933. Altain Suvun Uskonto. Porvoo \& Helsinki: Werner Söderström.

Hassanova \& Pevnov 2003 = Хасанова, Марина \& Певнов, Александр. Мифы и сказки негидальцев. Kyoto: Nakanishi Printing Co.

Helimski 1982 = Хелимский, Евгений. Самодийская мифология. Мифы народов мира 2. Москва: Советская энциклопедия, lk 398-401.

Hirschberg, Walter 1929. Die Plejaden in Africa und ihre Beziehung zum Bodenbau. Zeitschrift für Ethnologie 61, lk 321-337.

Holmberg (Harva), Uno 1927. The Mythology of All Races 4. Finno-Ugric, Siberian. Boston: Marshall Jones.

Homitš 1974 = Хомич, Людмила. Материал по народным знаниям ненцев. Социальная организация и культура народов Севера. Москва: Наука, lk 231-248.

Hose, Charles, \& McDougall, William 1912. The Pagan Tribes of Borneo 2. London: MacMillan.

Hudjakov 1969 = Худяков, Иван. Краткое описание Верхоянского округа. Ленинград: Наука.

Ishida 1998 = Исида, Эйитиро. Мать Момотаро. Исследование некоторых аспектов истории культуры. Пер. с англ. А.М. Кабанова. Санкт-Петербург: Петербургское Востоковедение.

Ichon, Alain 1969. La Religion des Totonaques de la Sierra. Paris: Centre National de la Recherche Scientifique.

Inoui, Koichi 2005. Eravestlus.

Its 1960 = Итс, Рудольф. Мяо. Историко-этнографический очерк. Москва \& Ленинград: Изд-во АН СССР.

Ivanova, Olga 2009. Eravestlus.

Jankovitš 1951 = Јанковић, Ненад. Астрономија у преданьима, обичајима и умотворинама срба. Српски етнографски зборник, књ. LXIII. Београд: Српска Академија Наука. 
Jegorov 1995 = Егоров, Н. И. Чувашская мифология. Скворцов, М. И (vast toim). Культура Чувашского края 1. Учебное пособие. Чебоксары: Чувашское книжное изд-во, lk 109-146.

Jegorov 2003 = Егоров, С. Б. Предания, легенды и мифологические рассказы вепсов. Мифология и религия в системе культуры этноса. Материалы Вторых СанктПетербургских этнографических чтений. Санкт-Петербург: Российский Этнографический Музей, lk 128-129.

Jevsejev 1981 = Евсеев, Виктор. Карельское народное поэтическое творчество. Ленинград: Наука.

Jochelson, Waldemar 1908. The Koryak. Leiden: E.J. Brill; N.Y.: G.E. Stechert.

Jochelson, Waldemar 1961. Kamchadal Texts. 'S-Gravenhage: Mouton.

Jones, William 1919. Ojibwa Texts. New York: Stechert.

Juhma 1980 = Юхма, Мишши. Заметки о чувашской космонимии. Ономастика Востока. Москва: Наука, lk 264-269.

Jüvä, Sullõv \& Kauksi Ülle \& Kõivupuu, Marju \& Reimann, Nele \& Hagu, Paul 1995. ABC kiräoppus ja lugõmik algkooli latsilõ. Võro: Võro Instituut ja Võro Selts.

Kaptšits 1997 = Капчиц, Георгий. Сомалийские народные сказки. Москва: Восточная литература.

Karuts 1911 = Карутц, Рихард. Среди киргизов и туркменов Мангышлака. СанктПетербург: Издание А.Ф. Девриена.

Kerbelyte 2001 = Кербелите, Бронислава. Типы народных сказаний. Структурносемантическая классификация литовских этиологических, мифологических сказаний и преданий. Санкт-Петербург: Европейский Дом.

Koekemoer, Gerhardus 2007. Lightning design in an African Content. Pretoria: Tshwane University of Technology.

Konakov jt 2003. Komi Mythology. Budapest: Akadémiai Kiadó; Helsinki: Finnish Literature Society.

Krappe, Alexander. 1938. La Genèse des Mythes. Paris: Payot.

Krappe, Alexander 1940. The lunar frog. Folk-Lore 51, lk 161-171.

Kreinovitš 1973 = Крейнович, Ерухим. Нивхгу. Загадочные обитатели Сахалина и Амура. Москва: Наука.

Kulemzin \& Lukina 1978 = Кулемзин, Владислав \& Лукина, Надежда. Материалы по фольклору хантов. Записи, введение и примечания В.М. Кулемзина и Н.В. Лукиной. Томск: Издательство Томского университета.

Kuperjanov, Andres 2001. Linnutee. Mäetagused 16, lk 107-116 (http://www.folklore.ee/ tagused/nr16/cps.pdf - 1. november 2010).

Kuperjanov, Andres 2003. Eesti taevas. Tartu: Eesti Folkloori Instituut.

Lantis, Margaret 1946. The Social Culture of the Nunivak Eskimo. Transactions of the American Philosophical Society 35 (3), lk 153-323. 
Laškarbekov, Bogšo 2005. Eravestlus.

László, Gáldi 1975. Orosz-magyar kéziszótár. Russko-vengerski slovar’. Budapest: Akadémiai Kiadó.

Laurinkene 2002 = Лауринкене, Нийоле 2002. Представления о месяце и интерпретация видимых на нем пятен в балтийской мифологии. Балто-славянские исследования 15. Сборник научных трудов. Москва: Индрик, lk 360-385.

Limerov 2005 = Лимеров, Павел. Ми puksiöm - Сотворение мира. Сыктывкар: Коми книжное изд-во.

Loorits, Oskar 2000. Liivi rahva usund IV-V. Tartu: Eesti Kirjandusmuuseumi rahvausundi töörühma väljaanne.

Lopatin, Ivan 1922 = Лопатин, Иван. Гольды амурские, уссурийские и сунгарийские. Опыт этнографического исследования. Владивосток: Записки общества изучения Амурского края владивостокского отделения приамурского отдела Русского Географического Общества 17.

Lukina 1990 = Лукина, Надежда. Мифы, предания, сказки хантов и манси. Пер. с хантыйского, мансийского, немецкого языков. Москва: Наука.

Lundmark, Bo 1982. Sol- och månkult samt astrala och celesta förestäningar bland samerna. Umea: Västerbotens Museum.

MacDonald, John 1998. The Arctic Sky. Toronto: Royal Ontario Museum.

Mahieu, Wauthier de 1975. Cosmologie et structuration de läespace chez les Komo. Africa 45 (3), lk 236-257.

Maksjutova 1973 = Максютова, Нажиба. Башкирская космонимия. Ономастика Поволжья. Материалы III Конференции по Ономастике Поволжья. Уфа: АН СССР, Башкирский филиал; Институт этнографии им. Н.Н. Миклухо-Маклая, Башкирский Государственный Университет, lk 382-384.

Mándoki, László 1963. Asiatische Sternnamen. Glaubenswelt und Folklore der sibirischen Völker. Budapest: Akadémiai Kiadó, lk 519-532.

Marinov 2003 = Маринов, Димитьр. Народна вяра. Избрани произведения в 5 тома. Том 1., част 1. София: Изток-Запад.

Matičetov, Milko 1974. Zvezdna imena in izročila o zvezdah med slovenci. Zbornik za zgadovino narodoslovja in tehnike 2. Ljubljana: Slovenska Matica, lk 43-90.

McClelland, Catharine 1975. My Old People Say. An Ethnographic Survey of Southern Yukon Territory 1. Ottawa: National Museums of Canada.

McIlwraith, Thomas 1948. The Bella Coola Indians 2. Toronto: University of Toronto Press.

Meek, Charles 1931. A Sudanese Kingdom. London: Kegan Paul, Trench, Trubner.

Miller, Douglas 1977. Stars of the First People. Boulder: Pruett.

Mitskevitš 1955 = Мицкевич, Адам. Пан Тадеуш. Перевод С. Мар (Аксеновой). Избранные произведения 2. Москва: Государственное издательство художественной литературы, lk 277-570. 
Mladenova 2006 = Младенова, Дарина. Звездното небе над нас. Етнолингвистично изследоване на балканските народни астрономи. София: Академично издателство Проф. Мария Дринов.

Moškov 1900 = Мошков, Валентин. Миросозерцание наших восточных инородцев: вотяков, черемисов и мордвы. Живая старина 10 (1-2), lk 194-212.

Mudrak, Oleg 2008. Eravestlus.

Munkácsi, Bernhard 1908. Die Weltgottheiten der Wogulischen Mythologie. Revue orientale pour les études ouralo-altä̈ques 9 (3), $1 \mathrm{k} 206-277$.

Munkácsi, Bernhard 1986. Wogulisches Wörterbuch. Budapest: Akadémiai Kiadó.

Nadršina 1985 = Надршина, Фануза. Башкирские предания и легенды. Уфа: Башкирское кн. изд-во.

Napolskihh 1990 = Напольских, Владимир. Палеоевропейский субстрат в составе западных финно-угров. Uralo-Indogermanica. Балто-славянские языки и проблема урало-индоевропейских связей. Материалы конференции. Часть 2. Москва: Институт славяноведения и балканистики, lk 128-134.

Napolskihh 1992 = Napolskikh, Vladimir. Proto-uralic world picture: a reconstruction. Northern Religions and Shamanism. Budapest: Akadémiai Kiadó; Helsinki: Finnish Literature Society, lk 3-20.

Napolskihh 1997 = Напольских, Владимир. Введение в историческую уралистику. Ижевск: УрО РАН.

Nekljudov jt 2007 = Неклюдов, Сергей. Материалы российско-монгольской фольклорной экспедиции 19.08-2.09.2007. Хубсугульский и Булганский аймаки. Москва: Архив Российского государственного гуманитарного университета.

Nelson, Edward 1899. The Eskimo about Bering Strait. Washington: Smithsonian Institution.

Nenjang 1997 = Ненянг, Любовь. Ходячий ум народа. Сказки, легенды, мифы, предания, эпические песни, пословицы, поговорки, поверья, обереги, народные приметы, загадки таймырских ненцев. Красноярск: Фонд северных литератур ХЭГЛЭН.

Nepokupnõi 2004 = Непокупный, Анатолий. От прус. BAYTAN E.346 'СИТО' к PAYCORAN E.6 'ПЛЕЯДЫ' как соответствию лит. SIEEÝNAS 'то же'. Балто-славянские исследования 16. Сборник научных трудов. Москва: Индрик, lk 65-82.

Nevski 1996 = Невский, Николай. Луна и бессмертие. Петербургское Востоковедение 8, lk 265-301.

Niebrzegowska 1999. Gwiazdy w ludowym jęzkowym obrazie świata. Językowy obraz świta. Lublin: Wydawnictwo Uniwersytetu Marie Curie-Skłodowskiej, lk 137-154.

Nikolajeva jt 1989 = Николаева, Ирина \& Жукова, Людмила \& Демина, Любовь. Фольклор юкагиров верхней Колымы (хрестоматия) 1. Якутск: Якутский государственный университет. 
Nikonov 1973 = Никонов, Владимир. Космонимия Поволжья. Ономастика Поволжья. Материалы III Конференции по Ономастике Поволжья. Уфа: АН СССР, Башкирский филиал; Институт этнографии им. Н.Н. Миклухо-Маклая, Башкирский Государственный Университет, lk 373-381.

Nikonov 1980a = Никонов, Владимир. География названий Млечного Пути. Ономастика Востока. Москва: Наука.

Nikonov 1980b = Никонов, Владимир. Материалы по космонимике Средней Азии. Ономастика Средней Азии. Фрунзе: Илим.

Nimuendaju, Curt 1952. The Tukuna. Berkeley: University of California Press.

Niskanen, Markku 2002. The origin of the Baltic-Finns from the physical anthropological point of view. The Mankind Quartely 43 (2), lk 121-153.

Noorem Edda 1970 = Младшая Эдда. Изд. подготовили О.А. Смирницкая и М.И. Стеблин-Каменский. Ленинград: Наука.

Novikova 1987 = Новикова, К. Эвенские сказки, предания и легенды. Магадан: Магаданское кн. изд-во.

Ostermann, Hother 1942. The Mackenzie Eskimos. After Knud Rasmussen's Posthumous Notes. Copenhagen: Fifth Thule Expedition.

Ostermann, Hother 1952. The Alaskan Eskimos as Described in the Posthumous Notes of Dr. Knud Rasmussen. Copenhagen: Fifth Thule Expedition.

Ovtšinnikov 1897 = Овчинников, М. Из материалов по этнографии якутов. Этнографическое Обозрение 3, lk 148-184.

Pechuël-Loesche, Eduard 1907. Volkskunde von Loango. Stuttgart: Strecker \& Schröder. Peebo, Kadri \& Peegel, Juhan 1989. Igal puul oma juur. Murdetekste Jakob Hurda kogust. Tallinn: Eesti Raamat.

Pelihh 1972 = Пелих, Галина. Происхождение селькупов. Томск: Изд-во Томского университета.

Pevnov, Alexander 2008. Eravestlus.

Pilsudski, Bronislaw 1912. Ainu folk-lore. Journal of American Folklore 25, lk 72-86.

Pilsudski 1991 = Пилсудский, Бронислав. Фольклор айнов. Краеведческий бюллетень общества изучения Сахалина и Курильских островов (Южно-Сахалинск) 3, lk 6984.

Podmaskin 1991 = Подмаскин, Владимир. Духовная культура удэгейцев. Владивосток: Изд-во Дальневосточного университета.

Podmaskin 2006 = Подмаскин, Владимир. Народные знания тунгусо-маньчжуров и нивхов: проблемы этногенеза и этнической истории. Владивосток: Дальнаука.

Pogodin 1895 = Погодин, А. Космические легенды балтийских народов. Живая Старина 5 (3-4), lk 428-448. 
Popov 1949 = Попов, Андрей. Материалы по истории религии якутов бывшего Вилюйского округа. Сборник Музея Антропологии и Этнографии. Москва \& Ленинград 11, lk 255-323.

Popov 1984 = Попов, Андрей. Нганасаны. Социальное устройство и верования. Ленинград: Наука.

Porotov \& Kossõgin $1969=$ Поротов, Георгий \& Косыгин, Владимир. В стране Кутхи. Из цикла “Встречи в тундре”. Петропавловск-Камчатский: Дальневосточное кн. изд-во.

Potanin 1881 = Потанин, Григорий. Очерки северо-западной Монголии. Результаты путешествия, исполненного в 1876-1877 годах по поручению Императорского Русского Географического Общества. Выпуск II. Материалы этнографические. Санкт-Петербург: типография В. Киршбаума.

Potanin 1883 = Потанин, Григорий. Очерки северо-западной Монголии. Результаты путешествия, исполненного в 1879 году по поручению Императорского Русского Географического Общества. Выпуск IV. Материалы этнографические. Санкт-Петербург: типография В. Киршбаума.

Potanin 1893 = Потанин, Григорий. Тангутско-тибетская окраина Китая и Центральная Монголия 2. Санкт-Петербург: типография А.С. Суворина.

Potanin $1919=$ Потанин, Григорий. Монгольские сказки и предания. Записки Семипалатинского подъотдела Западно-сибирского отдела Русского географического общества 13, lk 1-97.

Pustõlnik 2002 = Пустыльник, Изольд. Астрономическое наследие древних эстов и его отражение в фольклоре и искусстве. Потемкина, Т.M \& Обридко, В.H. (vast toim). Астрономия древних обществ. Материалы конференции “Астрономия древних цивилизаций” Европейского общества астрономии в культуре (SEAC) в рамках Объединённого Европейского и Национального астрономического съезда (JENAM). Москва: Наука, lk 283-285.

Rasmussen, Knut 1930. Observations on the Intellectual Culture of the Caribou Eskimos. Copenhagen: Fifth Thule Expedition.

Rassadin 1996 = Рассадин, Валентин. Легенды, сказки и песни седого Саяна. Тофаларский фольклор. Иркутск: Комитет по культуре Иркутской областной администрации, Областной центр народного творчества и досуга.

Ray, Carl, \& Stevens, James 1971. Sacred Legends of the Sandy Lake Cree. Toronto: McClelland \& Steward.

Reed, Alexander 1999. Maori Myths and Legendary Tales. Aukland, Sydney, London, Cape Town: New Holland Publishers.

Rodd, France 1926. People of the Veil. London: MacMillan \& Co.

Rodionov 1982 = Родионов, Виталий. К образу лебедя в жанрах чувашского фольклора. Чувашский фольклор. Специфика жанров. Чебоксары: НИИ языка, литературы, истории и экономики при Совете Министров Чувашской АССР, lk 150-170. 
Rudenko 1955 = Руденко, Сергей. Башкиры. Историко-этнографические очерки. Москва \& Ленинград: Изд-во АН СССР.

Rut 1987 = Рут, Мария. Русская народная астронимия. Учебное пособие. Свердловск: Уральский Государственный университет.

Rõtškov 1922 = Рычков, К.Н. Енисейские тунгусы. Землеведение 1-2, lk 69-106.

Sanžejev 1927 = Санжеев, Гарма. Дархаты. Этнографический отчет о поездке в Монголию. Ленинград: АН СССР.

Schefold, Reimar 1988. Lia. Das große Ritual auf den Mentawai-Inseln. Berlin: Dieter Reimer Verlag.

Schwab, George 1947. Tribes of Liberian Hinterland. Cambridge: Peabody Museum.

Seroševski 1896 = Серошевский, Вацлав. Якуты. Опыт этнографического исследования 1. Санкт-Петербург: Издание Императорского Русского географического общества.

Sicard, Harald von 1966. Karanga stars. Southern Rhodesia Native Affairs Department Annual 9 (3), lk 142-165.

Sidelnikov 1962 = Сидельников, Виктор. Казахские сказки 2. Алма-Ата: Казахское Государственное Изд-во Художественной Литературы.

Simtšenko 1966 = Симченко, Юрий. Традиционные верования нганасан 1. Москва: Институт этнологии и антропологии РАН.

Sirotkin \& Ivanov 1970 = Сироткин, Михаил \& Иванов, М. И. (toim). Чуваши. Этнографическое исследование 2. Духовная культура. Чебоксары: Книжное издательство.

Skeat, Walter W. \& Blagden, Charles O. 1900. Malay Magic. London \& New York: MacMillan Co.

Smith, William 1925. The Ao Naga Tribe of Assam. London: MacMillan \& Co..

Sorokina, Irina 2008. Eravestlus.

Speck, Frank 1915. Myths and Folklore of the Timiskaming Algonquin and Timagami Ojibwa. Ottawa: Canada Department of Mines.

Spieth, Jakob 1906. Die Ewe-Stämme. Berlin: Reimer.

Stasevich, Inga 2006. Eravestlus.

Steblin-Kamenski, Ivan 2008. Eravestlus.

Steinitz, Wolfgang 1966-1993. Dialektologisches und etymologisches Wörterbuch der ostjakischen Sprache. Berlin: Akademie Verlag, Lfg 1-15.

Svjatski 1961 = Святский, Даниил. Очерки истории астрономии в Древней Руси. Историко-астрономические исследования 7. Москва: Государственное издательство физико-математической литературы, lk 75-128.

Swanton, John 1908a. Haida Texts, Masset Dialect. Jesup North Pacific Expedition, Publication 10. Leiden, New York, lk 273-812. 
Swanton, John 1908b. Social conditions, beliefs, and linguistic relationship of the Tlingit Indians. 26th Annual Report of the Bureau of Ethnology. Washington: Smithsonian Institution, lk 391-485.

Šarakšinova 1980 = Шаракшинова, Надежда. Мифы бурят. Иркутск: Восточно-Сибирское кн. изд-во.

Zolotnitski 1874 = Золотницкий, Николай. Отрывки из чувашско-русского словаря 14. Чувашские названия Бога, неба и светил небесных. Казань: в губернской типографии, lk 1-23.

Zsigmond, Cyörö 2003. Popular cosmology and beliefs about celestial bodies in the culture of the Hungarians from Romania. Acta Ethnographica Hungarica 48 (3-4), lk 421-439.

Žukovskaja, Natalja 1988 = Жуковская, Наталья. Дархаты. Народы мира. Москва: Совецкая Энциклопедия, lk 151.

Teit, James 1898. Traditions of the Thompson River Indians of British Columbia. Boston, New York: American Folklore Society.

Teit, James 1909. The Shuswap. Memoires of the American Museum of Natural History 4, lk 443-813.

Thompson, Terry, \& Egesdal, Steven 2008. Salish Myths and Legends. Lincoln, London: University of Nebraska Press.

Toivonen, Yryö 1937. Pygmäen und Zugvögel. Finnisch-Ugrische Forschungen 24 (1-3), lk 87-126.

Tolokonski 1914 = Толоконский, Н. Якутские пословицы, загадки, святочные гадания, обряды, поверья, легенды и др. Собраны при ближайшем участии учителя-якута А. Кулаковского. Иркутск: Типография Т-ва М.П. Окунев и К.

Tsenev 2004 = Ценев, Горе. Небото над Македонија. Скопје: Младински културен центар.

Tšadajeva 1990 = Чадаева, Алина. Древний свет. Сказки, легенды, предания народов Хабаровского края. Хабаровск: Хабаровское кн. изд-во.

Tšarnolusski 1930 = Чарнолусский, Владимир. Материалы по быту лопарей. Ленинград: Издательство Государственного Русского Географического Общества.

Tšarnolusski 1962 = Чарнолусский, Владимир. Саамские сказки. Москва: Государственное издательство художественной литературы.

Tšubinski 1872 = Чубинский, Павел. Труды этнографическо-статистической экспедиции в Западно-русский край. Юго-западный отдел. Материалы и исследования собранные П.П. Чубинским 1. Санкт-Петербург: Имп. русс. геогр. общество.

Turajev 2008 = Тураев, В. А. (toim). История и культура нивхов. Историко-этнографические очерки. Коллективная монография. Санкт-Петербург: Наука.

Tutškova 2004 = Тучкова, Наталья (toim). Мифология селькупов. Томск: Изд-во Томского Университета. 
Urazalejev 2007 = Уразалеев, Руслан. Национальный фольклор сибиров среднего Прииртышья. (http://sybyrlar.narod.ru/folklor.html - 28. oktoober 2010).

Vaiškūnas, Jonas 1999. Etnoastronomia litewska. Etnolingwistika. 11, lk 165-175.

Vaiškūnas 2004 = Вайшкунас, Йонас. Народная астрономия белорусско-литовского пограничья. Балто-славянские исследования 16. Сборник научных трудов. Москва: Индрик, lk 168-179.

Vaiškūnas, Jonas 2006. The Moon in Lithuanian Folk Tradition. Folklore. Electronic Journal of Folklore 32, lk 157-184 (http://www.folklore.ee/folklore/vol32/moon.pdf 3. detsember 2010).

Valejev 1976 = Валеев, Фоат. О религиозных представлениях западносибирских татар. Вдовин, И. С. (toim). Природа и человек в религиозных представлениях народов Сибири и Севера (вторая половина XIX - начало XX в.). Ленинград: Наука, lk 320-331.

Vardugin 1996 = Вардугин, Владимир (toim). Мифы древней Волги. Мифы, легенды, сказания, быт и обычаи народов, обитавших берега великой реки с древнейших времен до наших дней. Составитель В. И. Вардугин. Саратов: Надежда.

Vassiljev 1907 = Васильев, М. Религиозные верования черемис. Уфа: Губернская типография.

Vassiljevitš 1936 = Василевич, Глафира. Материалы по эвенкийскому (тунгусскому) фольклору 1. Ленинград: Изд-во Института народов Севера ЦИК СССР.

Vassiljevitš 1959 = Василевич, Глафира 1959. Ранние представления о мире у эвенков (материалы). Труды Института Этнографии 51, lk 157-192.

Vassiljevitš 1969 = Василевич, Глафира. Эвенки. Историко-этнографические очерки (XVIII-начало XX в.). Ленинград: Наука.

Vathanaprida, Supaporn 1994. Thai Tales. Englewood: Libraries Unlimited.

Vereštšagin 1995 = Верещагин, Григорий. Собрание сочинений 1. Вотяки Сосновского края. Ижевск: УрО РАН, Удмуртский институт истории, языка и литературы.

Vladõkin 1994 = Владыкин, Владимир. Религиозно-мифологическая картина мира удмуртов. Ижевск: Удмуртия.

Volpati, Carlo 1932. Nomi romanzi degli astri Sirio, Orione, le Pleiadi e le Jadi. Zeitschrift für romanische Philologie 52, lk 151-211.

Volpati, Carlo 1933a. Nomi romanzi delle Orse, Boote, Cigno e altre costellazioni. Zeitschrift für romanische Philologie 53, lk 449-507.

Volpati, Carlo 1933b. Nomi romanzi della Via Lattea. Revue de linguistique romane 9, lk $1-51$.

Vorobjov \& Hissamutdinov 1967 = Воробьев, Н. И. \& Хисамутдинов, Г. М. Татары Среднего Поволжья и Приуралья. Москва: Наука.

Voskoboinikov 1960 = Воскобойников, Михаил. Эвенкийский фольклор. Учебное пособие для педагогических училищ. Ленинград: Учпедгиз. 
Voskoboinikov 1967 = Воскобойников, Михаил. Фольклор эвенков Прибайкалья. Записал и обработал проф. М.Г. Воскобойников. Улан-Удэ: Бурятское кн. изд-во.

Wichmann, Yrjo 1987. Wotjakischer Wortschatz. Helsinki: Société Finno-ougrienne.

Williamson, Robert 1933. Religious and Cosmic Beliefs of Central Polynesia 1. Cambridge: University Press.

Wolf, Werner 1929. Der Mond in deutschen Volksglauben. Bühl (Baden): Konkordia.

\section{Summary}

\section{The Pleiades as Openings, The Milky Way as the Path of Birds, and the Girl on the Moon: Cultural Links Across Northern Eurasia}

Juri Berezkin

Keywords: Asian-American cosmonymic links, folk astronomy, lunar spots, prehistory of Northern Eurasia, the Milky Way, the Pleiades

The Baltic-Finnish and the Baltic (Latvian and Lithuanian) cosmonyms mostly coincide while the Baltic and Slavic cosmonymic patterns are different. The Pleiades in the Eastern Baltic are "a sieve", the Milky Way is "the path of migratory birds" and a girl holding water pails is seen on the Moon. Across most of Central, Western and Southern Europe the Pleiades are "a hen with its chicken", the Milky Way and the lunar spots have other (and different) interpretations. The Eastern Baltic pattern is identical with the Middle Volga one where it is widespread among both Finnish-Permian and Turkic groups and probably relates back to the (Proto-Baltic?) culture of the Iron Age. However, parallels for the cosmonyms in question are found across most of Northern Eurasia and find corresponding similarities in some parts of North America. "Water-carrier on the Moon" is the most widespread of these motifs being known in Japan and Polynesia. In Eurasia, the Northern Samoyeds noticeably lack all three images. The initial emergence of at least some of the cosmonyms under discussion in the Terminal Pleistocene of northern East Asia and their further dissemination towards the West, down to the Baltics, is a hypothesis to be checked. 